\title{
ISLAM NUSANTARA AS A COUNTER-HEGEMONY AGAINTS THE RADICALISM OF RELIGION IN INDONESIA
}

\author{
Khoirurrijal \\ IAIN Metro, Lampung \\ khoirurijal@yahoo.com
}

\begin{abstract}
Abstrak
Tulisan ini membahas tentang Islam Nusantara sebagai counter-hegemony melawan Radikalisme Agama di Indonesia. Berdasarkan kajian yang dilakukan terdapat relevansi atas apa yang diwacanakan Gus Dur dengan beberapa gejala yang muncul pada Islam Indonesia saat ini. Pertama, Pandangan Jihad yang keliru disebagian tubuh kalangan Islam sendiri yaitu munculnya terorisme secara terbuka yaitu gerakan ISIS di Indonesia. Kedua, Kekerasan atas nama agama semakin merebak yaitu oleh kalangan Islam Garis Keras seperti Front Pembela Islam (FPI), Forum Umat Islam (FUI), Majelis Mujahiddin Indonesia (MMI) dan lain-lain. Ketiga, Munculnya kembali perdebatan soal Pancasila dan Khilafah terutama digaungkan oleh Hibut Tahrir Indonesia (HTI) dan beberapa kalangan Islam yang mendukung perseteruan Khilafah vis a vis Pancasila. Dalam membahas Islam nusantara, penulis mendayagunakan teori counter-hegemony Antonio Gramsci dimana perlawanan atas radikalisme agama dilakukan dengan melakukan budaya tanding dengan wajah Islam yang toleran. Oleh sebab itu, tulisan ini akan mengupas dan menjelaskan secara mendalam wacana Islam Nusantara dengan manarik jauh atas gagasan yang dikenalkan oleh Gus Dur yaitu melalui pribumisasi Islam-nya sejak era 80-an sampai gagasan Islam Nusantara yang dimunculkan PBNU saat ini. Sehingga dapat dicapai suatu pengetahuan (knowledge) dan pemahaman (verstehen) menuju peradaban Islam Nusantara yang menghargai pluralitas, toleran dan rahmatan lil alamin.
\end{abstract}

Kata kunci: Islam Nusantara, dan Counter-Hegemony, dan Radikalisme Agama

\begin{abstract}
This paper discusses about Islam Nusantara as a counter-cultural hegemony againts the radicalism of religion in Indonesia. Based on studies conducted there is relevance for what discured Wahid with some symptoms that appear in Islamic Indonesia at this moment. First, the view of Jihad according to among Muslims, namely the emergence of terrorism openly i.e. movement of ISIS in Indonesia. Second, Violence in the name of religion is increasingly spread by the Hard-line Islamic circles such as the Islamic Defenders Front (FPI), Muslim Forum (FUI, Indonesian Mujahideen Council (MMI) and others. Third, the reappearance of the debate the question of Pancasila and the Caliphate was mainly undertaken by Hizbut Tahrir Indonesia (HTI) and some Islamic circles that supported caliphate feud vis a vis the Pancasila. In discussing Islam Nusantara, the authors utilize the theory of counter-hegemony Antonio Gramsci where resistance against religious radicalism is done by doing a counter culture with the face of a tolerant Islam. Therefore, this article will discuss and explain in depth discourse of Islam Nusantara with interested much on the idea introduced by Gus Dur, namely through its indigenization of Islam since the '80s. In order to achieve a knowledge and understanding (verstehen) toward Islam Nusantara civilization that respects plurality, tolerance and rahmatan lil Alamin.
\end{abstract}

Key words: Islam Nusantara, Counter-Hegemony, Radicalism of Religion and Antonio Gramsci 


\section{Introduction}

Islam Nusantara became interesting issues both before and after the Congress at to-33 Nahdlatul Ulama (NU) in Jombang, East Java, on a 1-5 August 2015. The large administrators NU seriously carry it into interesting theme that was "Meneguhkan Islam Nusantara sebagai Peradaban Indonesia dan Dunia".On the other hand with a span intersecting the 47th Muhammadiyah Congress held in Makassar on August 3 to 7, 2015 by the theme "Gerakan Perubahan Menuju Indonesia Berkemajuan." In the debate line media, the theme of 'Islam Nusantara' was the theme of the most controversial because the dynamics and many Islamic intellectual discourse that gives feedback. ${ }^{1}$

In line with the President Jokowi apparently also supports ${ }^{2}$ the idea of 'Islam Nusantara' as Islam rahmatan lil Alamin and in line with the roots of Indonesian culture. The President seemed to assure that we are a nation that is different from the Arab culture that has been filled with conflict "Arab Spring". ${ }^{3}$ President Jokowi as if to express the issue of radicalism in the name of religion in the Arab world not to happen in Indonesia.

If viewed from the perspective of culture, a theme raised by the two organizations have complementary look. NU has a typical traditional discourse 'Islam Nusantara' as a form of Islam that still preserve local culture. ${ }^{4}$ Meanwhile, since the beginning of Muhammadiyah which has a typical modernist Islamic movement as an organization expressing the enlightenment movement. The historical development of Islam in the archipelago obviously faced waves of updates above. 5 "Islam Berkemajuan" in the sense of liberating, empowering and advancing life. In essence, there is no serious contradictions in the current Cultural Hegemony. Indonesia's second large organizations even reinforce Islam Indonesia pluralistic and tolerant and have a great contribution to the world of Islamic civilization. ${ }^{6}$

In the late 1980's the theme of "Pribumisasi Islam" has been asked by Wahid. As more Wahid thinking, the nation of indigenization of Islam was also reaping the pros and cons, especially when 'assalamu'alaikum' equated with 'ahlan wa Sahlan' or 'shabah al-Khayr'. That is said Wahid, greetings can be replaced 'good morning' or 'hello'. The idea for the indigenization of Islam is known only to make a commotion among NU.Until finally from 8-9 March 1989 about 200

1http:// www.nu.or.id/post/read/59035/apa-yang-dimaksud-dengan-islam-nusantara downloaded 20 July 2016

${ }^{2}$ http:// www.jpnn.com/read/2015/06/14/309550/Jokowi:-Alhamdulillah,-Islam-KitaIslam-Nusantara downloaded on 20 July 2016

${ }^{3}$ Agastya.M.ABM.. Arab Spring Badai Revolusi Timur Tengah yang Penuh Darah. (Jogjakarta: IRCiSoD, 2013)

${ }^{4}$ Nurcholis Madjid, Islam, Doktrin dan Peradaban (Jakarta: Paramadina, 1992), 552

${ }^{5}$ Martin van Bruinessen, "Global and local in Indonesian Islam" Shouteast Asian Studies Vol.37 No.2 (1999), h. 158-175; dan Azyumardi Azra, Islam Nusantara: Jaringan Global dan Local (Bandung: Mizan, 2002)

6R.E. Elson, "Islam, Islamism, the Nation and the Early Indonesian Nationalist Movement" Journal of Indonesian Islam Vol.1 No.2 (2007), p.231-266. 
Kiai have gathered at Darut Tauhid Arjawinangun Cirebon boarding school to 'prosecute' Wahid. However, as recognized by Wahid himself, he was not the first to start. He is the successor generation of step strategy that has ever run by Walisongo.7 With the indigenization step, he said, Walisongo managed to convert the land of Java, without encountering and experiencing the tension with the local culture. ${ }^{8}$

This paper attempts to review Islam Nusantara discourse is echoed in all 33 NU in Jombang. As a cultural discourse, Islam Nusantara become part responds to foreign cultures intriguing traditions and religious diversity especially for the NU. This discourse is connected with a discourse by Abdurrahman Wahid (Gus Dur) ${ }^{9}$ since the ' 80 s writing about 'Pribumisasi Islam'. ${ }^{10}$

Gus Dur realized from the start there was a logic mischaracterized the two terms, namely 'Islamisation' and 'Arabization'. Gus Dur explicitly stated that Islam is different from the Arabs. To this day the debate still continues to grow and gain momentum peak in discourse 'Islam Nusantara'. What was discoursed by Gus Dur necessarily relevant to some of the symptoms that appear on Islam in Indonesia today. First, Jihad erroneous view ${ }^{11}$ in part of the body of Islam it self is the emergence of terrorism openly namely ISIS movement in Indonesia. ${ }^{12}$ Second, Violence in the name of religion is increasingly spread by the Hard-line Islamic circles such as the Islamic Defenders Front (FPI), ${ }^{13}$ Muslim Forum (FUI), ${ }^{14}$ Majelis Mujahiddin Indonesia (MMI), ${ }^{15}$ and others. Third, the reappearance of the debate the question of Pancasila and the Caliphate was

${ }^{7}$ Ahmad Baso, NU Studies: Pergolakan Pemikiran aatara Fundamentalisme Islam dan Fundamentalisme Neo-Liberal(Jakarta: Erlangga, 2006), p.284.

8 Khamami Zada dkk., "Islam Pribumi: Mencari Wajah Islam Indonesia", dalam Jurnal Tashwirul Afkar, No. 14 (Jakarta: Lakpesdam, 2003), p.9-10.

${ }^{9}$ Kiai Haji Abdurrahman Wahid, familiar called Wahid (born in Jombang, East Java, 7 September 1940 - died in Ciganjur, December 30, 2009 at the age of 69 years) was a prominent Muslim Indonesia and political leader who became the fourth President of Indonesia from 1999 to 2001. He replaces President B. J. Habibie after it was elected by the people's Consultative Assembly Election 1999 results. The Organization of his Government, assisted by a Cabinet of national unity.Abdurrahman Wahid's Presidency began on October 20, 1999 and ended on the MPR special session in 2001. Right, July 23, 2001, his leadership was replaced by Megawati Sukarnoputri after his mandate was revoked by the MPR. Wahid is a former Chairman of the Tanfidziyah (Executive Body) of the Nahdlatul Ulama and the founder of the National Awakening Party (PKB).

10Abdurrahman Wahid, "Pribumi Islam" dalam Muntaha Azhari \& Abdul Mun'im Saleh (eds.), Islam Indonesia Menatap Masa Depan (Jakarta: P3M, 1989),p. 83.

${ }^{11}$ Azyumardi Azra, Agama dan Otentisitas Islam(Jakarta: Paramadina, 2004), p.77.

12 Haidar Assad, Muhammad. ISIS Organisasi Teroris Paling Mengerikan Abad Ini. (Jakarta: Zahira, 2014)

13 Ninin Prima Damayanti, Imam Thayibi, Listya Adi Gardhiani, Indah Limy, Radikalisme Agama Sebagai Salah Satu Bentuk Perilaku Menyimpang: Studi Kasus Front Pembela Islam, Jurnal Kriminologi Indonesia Vol. 3 No. I Juni 2003 : 43 - 57

${ }^{14}$ Khamami Zada, Islam Radikal : Pergulatan Ormas-ormas Islam Garis Keras di Indonesia, (Jakarta : Teraju, 2002)

${ }^{15}$ MMI was formed as a forum for a number of Indonesian Muslim leaders to carry out the mission of the enforcement of Islamic law, to be exact, to enforce all the rules of life taught by the religion of Islam is derived from the Qur'an and the Sunnah of the Prophet Muhammad, see Muhammad Anshor, Kemunculan Radikalisme Islam Indonesia Pasca Suharto (Pekanbaru: Jaringan Studi Pemberdayaan Demokrasi Lokal , 2007), p. 12. 
mainly undertaken by Hizbut Tahrir Indonesia (HTI) ${ }^{16}$ and some Islamic circles that supported Caliphate feud vis a vis the Pancasila. ${ }^{17}$ The phenomenon is part of radicalism in the name of religion were very militant build from the grassroots movement. 18

This paper dissects the discourse of indigenization of Islam and Islam Nusantara being warm discourse. As a country that has a background and ethnic and cultural richness, ${ }^{19}$ the Earth Indonesia is rich in diversity. The mindset is dangerous especially religious radicalism, ${ }^{20}$ could threaten the integration of the nation and threatening the survival of local culture itself. Then the dynamic cultural Islam found space in building harmony amid differences of religious interpretation.

"Pribumisasi Islam" movement has ever been considered by Gus Dur, adapting the universal values of Islam and defending local values that grow for a long time in the community. "Pribumisasi Islam" is a concept of understanding Islam whichis build on dialogue and local culture in order to form new traditions and it accordances with the spirit of the mutual in Indonesia.

Furthermore, Islam Nusantara is also increasingly established characteristic of Islamic Indonesia with a plural and tolerant without removing the essence of Islam itself. This paper studies utilizing the theory of Counter-Hegemony Gramsci to dissect the discourse of " "Pribumisasi Islam" and Islam Nusantara ' in its contribution to the civilization of Islam in a globalized world.

\section{Discussing}

The prior research of indigenization of Islam has been done by various institutions and researchers, such as research M. Khoirul Hadi (2015)," Abdurrahman Wahid dan Pribumisasi Pendidikan Islam, Hunafa: Jurnal Studia Islamika21, Nur Kholiq, (2010) Pribumisasi Islam Dalam Perspektif Gus Dur. ${ }^{22 B a s e d}$ on Indonesian Islamic Studies even global study of religion in relation to religious plurality can not deny pluralism of thought leaders of Indonesia, Abdurrahman Wahid (Gus Dur). The Former Chairman of the NU was known has such a very strong intellectual tradition, especially related to the study of religious issues. Coinciding with the second anniversary of the Wahid Institute,

16Zeyno Baran, Hizbut-Tahrir, Islam's Political Insurgency (Washington: The Nixon Center, 2004), p. 16.

17Abdurrahman Wahid, "Yang Samadan Yang Benar" diterbitkan kembali dalam kumpulan tulisannya, Tuhan Tidak Perlu Dibela (Yogyakarta: LKiS, 1999),p. 68-71

18 M. Imaduddin Rahmat, Arus Baru Islam Radikal, Transmisi Revivalisme Islam Timur Tengah ke Indonesia (Jakarta: Erlangga, 2005)

${ }^{19}$ Abdurrahman Wahid, "Pribumi Islam" dalam MuntahaAzhari\& Abdul Mun'im Saleh (eds.), Islam Indonesia Menatap Masa Depan(Jakarta: P3M, 1989), p.83.

20 Bahtiar Effendy dan Hendro Prasetyo. Radikalisme Agama.(Jakarta :PPIM, 1998)

21 M. Khoirul Hadi, Abdurrahman Wahid dan Pribumisasi Pendidikan Islam, Hunafa: Jurnal Studia Islamika, Sekolah Tinggi Islam Syalafiyyah Kencong Jember. Jurnalhunafa.org, Vol. 12, No. 1, Juni 2015: 183-207,

22 Nur Kholiq, Pribumisasi Islam Dalam Perspektif Gus Dur: Studi Kritis Terhadap Buku Islamku, Islam Anda, Islam Kita". (Skripsi UIN Sunan Kalijaga Yogyakarta: 2010) 
Gus Dur launched his book entitled "Islamku, Islam Anda, Islam Kita". The book contains a collection of articles which have ever been written by Gus Dur, which in concerned with understanding and definition of the religion (Islam) in Indonesia in the context of pluralism. Therefore, the book was at least able to make a contribution and enlightenment or precisely the criticism amid the throes of a religious issues often occur in Indonesia. Pribumisasi Islam Gus Dur as a discourse can make a positive contribution to the life of the nation in Indonesia, especially in relation to religious understanding. The implementation can realize the religious life of tolerance and harmony. While the movement in perspective, the idea of Gus Dur could be a form of antithesis or the solution of the contradiction between the fundamentalist Islam and Islam liberal movement. Pribumisasi Islam encourages the appearance of Islamic manners or smilling and could accommodate the strengths and values the local culture as well.

Such an exposure above, the importance of the concept of indigenization of Islam as the basis of thought embracing the local culture, so the face of religion is able to bring 'harmony' and 'tolerance' at the same contribution to the dynamics of reform Islamic thought in Indonesia. ${ }^{3}$ For example, through education, indigenization of Islam is able to translate religious beliefs so as to adjust to the local culture without losing the essence of monotheism.

Tradition is not a dead object, but rather a tool that lives to serve people who live anyway. ${ }^{24}$ Religion is a cultural expression of the confidence vote against something sacred. The culture affects the way a person's religious viewpoint. Then it is difficult to accept when a person can be pure religion without interference from the surrounding culture. The cultural environment established a tradition that is often intermingled with the patterns of religious practice, especially concerning religion other horizontal relationships as in the implementation transendent is man's relationship with God. So in the debate over religious truth that territory on horizontal implementation of religious expression are believed every person is an expression of culture that tends to multiple interpretations and is relative to the truth of God is absolute. ${ }^{25}$ One example of when Muslim Scholars debate the cultural expression of the religious institution among citizens of the NU, about Yasinan and Tahlilan problem, on the other hand among the Muhammadiyah is not running the cultural expression, then it needs that two Islamic organizations are above the concept of multiculturalism awareness of religious culture on Earth.

The open attitude to each other and appreciate the very important thing to do, given the belief something is interpreted differently can also trigger a schism in the community and even worse a prolonged conflict. Moeslim Abdurrahman mentions the cultural expression of this Indonesia Muslims by calling Islamic p. 111.

${ }^{23}$ Abdurrahman Wahid, Pergulatan Negara, Agama, dan Kebudayaan(Jakarta: Desantara, 2001),

24WS Rendra. Mempertimbangkan Tradisi. (Jakarta: PT Gramedia, 1981) p. 3.

25Moeslim Abdurrahman, Islam sebagai Kritik Sosial, (Jakarta: Penerbit Erlangga, 2003) p. 149. 
culturally conditioned.In the conflict that is common at the local level, not infrequently involve issues concerning religion, customs conflict, then further about politics and economics. Religious conflicts tend to be more effectively used to cover the struggle for economic resources which occur in an area. Religion present in Indonesia in practice bound with Indonesian culture.

When Islam first appeared in Arabic, then Islam met with results of a blend of Christian-Jewish tradition on the one hand and on the other hand is a combination of Persian-Arabic tradition. In the view of cultural Islam, ${ }^{26}$ Islamic Arab could not globalizein Indonesia, Islamization process was always experiencing acculturation or cultural values in the customs of local people. Spirit safely Islam certainly different to the spirit of Arabization. ${ }^{27}$

\section{From Pribumisasi Islam}

The group Nahdlatul Ulama (NU) with the progressive spirit of Pribumisasi Islam, continue to build the Post-Islamic traditionalism. Abdurrahman Wahid, one of the characters that can not be missed in the tradition of Islamic indigenization archipelago, even when the project is also still blocked the Great Wall in its environment. But Gus Dur efforts have resulted among the young generation in sowingthe NU progressivism. According to Johan Effendi indigenization of Islam began to be successful among NU during Gus Dur became NU Leader. Johan said that the project updates including indigenization of Islam in the NU impressive run so as not to cause turmoil among senior students and Kiai elderly. Gus Dur, along with young people of $\mathrm{NU}$, has provided the basics are very useful to put NU in going through the basic indigenization of Islam. ${ }^{28}$

Nahdlatul Ulama (NU) under the leadership of Gus Dur NU has made not only the Islamic organization known Indonesian society, but internationally as well.29.Gus Dur introduced the campus community, non- governmental organizations (NGOs), as well as foreign researchers who had not previously been familiar with NU in the international arena ${ }^{30}$.

Gus Dur contributed so extensively in NU, especially among young people. Young man sort of Masdar Farid Masudi, MM Billah, Arief Mudasir, Abdul Munim, Imam Aziz, M. Fajrul Falaakh, Ahmad Suaedy, M. Jadul Maula, with his LKiS, Ulil Abdlla with 68 studies in Jakarta, and Abd. A'la in East Java is the outcome of their friendship with Gus Dur. There are of course many young

26 Zainul Milal Bizawie, "Dialektika Tradisi Kultural: Pijakan Historis dan Antropologis Pribumisasi Islam", dalam Jurnal Tashwirul Afkar, No. 14 (Jakarta: Lakpesdam, 2003), p.51.

${ }^{27} \mathrm{Abd}$ Moqsith Ghazali dan Mustafa Basyir Rasyad, Islam Pribumi: Mencari Model Keberislaman ala Indonesia", in Komaruddin Hidayat and Ahmad Gaus Af (ed.) Menjadi Indonesia: 13 abad Eksistensi Islam di Nusantara, Mizan, (Bandung: Mizan, 2006), p. 658-659

${ }^{28}$ Djohan Effendy, Pembaruan tanpa Menabrak Tradisi, (Kompas, 2010)

${ }^{29}$ Greg Barton, Biografi Gus Dur (Yogyakarta: LKiS, 2006),p. 35.

30 Dedi Junaidi, Beyond the Symbols: Jejak Antropologis Pemikiran dan Gerakan Gus Dur (Bandung: PT. Remaja Rosda Karya, 2000), p.4. 
people who become educated by Gus Dur. Gus Dur as the chairman of the NU quite a long time since 1984-1999 has contributed so much so that NU is not only 'known' by the Indonesian Muslim population, but the population of the world, particularly the observers and researchers about the indigenization of Islam or Pribumisasi Islam .

The young got a very spacious room of Gus Dur to express their Islam, sometimes under pressure from the elderly in NU, but Gus Dur became 'defender and protector'. What do P3M, LKiS, Lakpesdam NU, LKPSMNU, Rahima, and Fahmina and a few others are the result of upbringing Gus Dur in building intellectual tradition and NGOs in Environmental NU. Now almost certainly all foreign researchers who want to investigate NU must refer to the institutions that had been criticized as a 'destroyer NU'. These institutions are now instead be Idol and worshipped among NU. KH. Abdul Qadir, KH. Husein Muhammed, KH. Abd Moqsith Ghazali are the next generations who succeeded the progressive muslim movement of NU.

After Gus Dur managing to instill the ideas of renewal through the progressive tradition of young people in the Neighborhood Governmental Organization (LSM) entered boarding school. Nowadays, young people of NU are rolling to reform in boarding schools with the spirit of Gus Dur as the first did.Of course, there is a boarding school that refused to accept the idea but most of the updates that done bythe young of NU. This is due to the idea of updates done by the young of NU had the support of the Kiai who has vision and thoughts relative equal to the young of NU

If the first of what was known as traditionalism is NU 'tacky' are not techsavvy, just dwellig on the classics (yellow book) it is now the traditionalists may be namedas more progressive than what was originally known as the reformer. It is true that the young groups in NU also faced opposition from NU Kiai, but some Kiai in the NU providing support and adequate space for young people to make updates in its tradition.This marked the successfull of the activities formerly resisted when Gus Dur beginning of reforms in the traditional boarding schools with various ideas of indigenization of Islam. ${ }^{31}$

The question is, what about the future of indigenization of Islam dealing with movements of purification are implicated should put forward so putting neo-Islamic traditionalism becomes increasingly precise position? This is the big question and must be answered by generation after the death of Gus Dur and should be followed by KH. Said Aqiel Siradj, as the chairman of the NU replacement $\mathrm{KH}$. Hasyim Muzadi after two periods leading NU as a substitute Gus Dur who in many cases could be said to be in unline with the idea of Gus Dur, including in politics. KH. Said Aqiel Siradj thus has such a heavy duty escort NU for five to ten even fifteen years from now, because now is the figure

${ }^{31}$ Abdurrahman Wahid, Islamku, Islam Anda dan Islam Kita, (Jakarta : The Wahid Institute,2008), p. 34 
of scholars who have positions such as Gus Dur NU in the body no longer exists.In any case, the position of Gus Dur can indeed be said to be 'privileged' than other Kiai in the NU, though other Kiai in Islamic scholarship is not inferior to Gus Dur.

KH. Said Aqiel Siradj, KH. Masdar Masudi, KH. Husein Muhammad and many more in the ranks tanfidiyah is figure scholars who have fluency in Islamic sciences, but it still can not replace the position of Gus Dur in the heart of the NU community. Similarly, sincerity and eloquence KH. Ali Yafie, KH. Sahal Mahfudz, KH. Faqih, would still be in a level that can be said to be under the charismatic Gus Dur,though KH. Fakih by Wahid placed as Kiai with the late langitan KH. Wahid Zaini and KH. As'ad Syamsul Arifin.

\section{Counter Hegemony by Islam Nusantara}

The model for the Islamic-inclusive pluralist and Islam substansialisme often collide with the formalization of Islamic law in Indonesia models Indonesian Mujahideen Council (MMI), Hizbut Tahrir Indonesia (HTI), the Islamic Defenders Front (FPI), and the Muslim Forum (FUI). ${ }^{32}$ The classification of neo-modernism that is inclusive pluralist Islam is often addressed on Pakistani thinker Fazlur Rahman, who in Indonesia then often addressed to Nurcholish Madjid and Ahmad Syafii as his student at the University of Chicago while learning about Islam. Besides Nurcholish Madjid and Syafii, Muslim scholars addressed to the category of neo-modernism is Gus Dur and Djohan Effendi. ${ }^{33}$ While M. Syafii Anwar, entered Syafii in the category of Neo-Modernist Islam as well substansialist, together a kind of Muslim scholar Jalaluddin Rachmat, even Taufik Abdullah. While Azyumardi Azra and M. Amin Abdullah as the new generation of Indonesian muslim scholar characterized substansialist ethics. ${ }^{34}$

As disclosed Azyumardi Azra ${ }^{35}$ that the worsening position of Muslim states in the north-south conflict the main support the emergence of radicalism. The formalization of Islamic Sharia is the primary concern by Gus Dur for a long time. At the end of this movement negated the dialogue between cultures as mixing up the order of Arabic culture with Islamic values. Gramsci calls this condition as hegemony. That 'hegemony' is occurred with the acquisition of the ideological source. Arab hegemony, for example will take place in the archipelago with the result in the value of existing local clash. Hegemony is done in the form of persuasive instill ideology to control the mind class or walks of life underneath, ${ }^{36}$ without any coercion. This hegemony achieved politically through 34.

32 Azyumardi Azra, Shari'at Islam dalam Bingkai Nation State (Jakarta: Paramadina, 2004), 33-

${ }^{33}$ Ahmad Syafii Maarif, Islam dan Masalah Tata Negara, (Jakarta : LP3ES, 1987), p. 21

${ }^{34}$ Qodir, Zuly, Pembaruan Pemikiran Islam, (Yogyakarta : Pustaka Pelajar, 2006), p. 16

35 Azyumardi Azra, Islamic Political Upheaval, from the Fundamentalist, Modernism to PostModernism", (Jakarta: Paramadina, 1996), p. 18.

36 M. Clark, Antonio Gramsci and the Revolution that Failed (New Haven: Yale University Press,1977), p. 2 
the efforts of moral and intellectual to create uniformity of views in a society. Hegemony in another sense also done by those who affected the foreign culture thereby eliminating local values are good.

Gramsci developed the concept of hegemony with its leadership rests on 'the intellectual and moral'. Leadership is due to the voluntary consent of the lower class or upper class of society to lead, ${ }^{37}$ particularly approval of the major groups in a society. ${ }^{38}$ Gus Dur to the conception of indigenization of Islam has instilled moral and intellectual movement to preserve local traditions are fused with religious values.

Because of the hegemony is accomplished through approval of the main groups in the community, then the agreement does not contain negative meanings, but quite the opposite. An Act, rules, or policies taken upon approval means good. The approval of the lower classes occurred due to upscale successful in instilling the ideology of the group. Ideological internalization is done by building a system and institutions, such as state, commen sense, culture, organization, education, and so on, to 'cement' or strengthen the hegemony.

The Neo-modernist muslim groups with the idea of carrying the inclusifisme of Islam and Islamic substansialisme evident not scheduled the need for Islamic formalisasi in the form of the State. Islam Nusantara, undertaken for example, NU is not a formalist Islam in the sense of the country must be based on Islam. They believe that the principle of Pancasila was already considered quite as the shapes of basic Islamic organization.The values of Pancasila, none of these are contrary to Islamic values. Therefore, neo-modernist Muslims have not scheduled the need to formalize Indonesia becoming an Islamic State as the Khilafah Islamiyah especially with the agenda and the caliph as head of State. Neo-modernist Muslim groups over how to keep the agenda of ethical principles of Islam can contribute to the management of the State, including in terms of politics, law and economics. Therefore, the agenda of the neo-modernist Muslims is how to transformate the Islamic ideals of ethics become such a reality in the life of a nation and state in Indonesia. As the goals and ideals of Islam has ethical principles that can be used as a foothold in the state without having formalized. ${ }^{39}$

The ideals of Islam that ideal even collide with reality if the conditions imposed on other forms of formalization. In this connection actually want to say by neo-modernists is how to bring the ideals of Islam as the reality of Islam archipelago or Islam Nusantara. For this reason social engineering is needed. Social engineering will run properly when the Muslims were able to locate the position of normative Islam in historical reality, because the ideals of normative

37 Gramsci, Antonio. Selection From The Note Hoare and Nowell Smith (ed). New York: International Publishers. 1976.

${ }^{38}$ Bocock, Robert, Pengantar Komprehensif untuk Memahami Hegemoni, terj. Ikramullah Mahyuddin(Yogyakarta: Jalasutra, 2007), p. 22-23

39 Abdurrahman Wahid, Tabayun Gusdur: Pribunisasi Islam, Hak Minoritas, Reformasi Kultural (Yogyakarta: LKiS,1998), 235. 
and historical reality often occurs collisions. In terms of political Islam, for example, Azyumardi Azra prefer how ethical or substance of Islam can influence the political life and the welfare of Indonesian people are still in a lower standard of poverty and welfare. ${ }^{40}$

Amin Abdullah in many of his writings introduced in clicking the need to download the derivation of Islamic ethics in everyday life. Even in the case of interreligious relations, the relationship between social and religious should be separated into an area where the normative and historic region. Which is said to be absolute is normative area while the historical area is a region of relative.

Amin Abd puts the position of Islam is not in terms of formalism but in the position of the need to repeal over the interpretation of the interpretation of Islam-had ever done by the scholars and clerics classic 6th century-7th Hijri century 13-16 AD. Reinnterpret muslim cleric and scholar's understanding of the middle ages did not mean unappreciated but very appreciated in the spirit of doing the ijtihad and reconstruction based on historical understanding of the community that continues to grow. ${ }^{41}$

In the area of civil society, the lasting of hegemony because of the civil society represented the moral ethics as to instill the ideology of the mechanism of the upper class. On the other hand, the hegemony againsts the lower classes is not always smooth running, obstacles, and obstacles could have come, especially from the classes who did not receive such a hegemony. That was done to handle the disagreement was done with the repressive domination action through the apparatus of the State, such as police.

Two leaderships, domination and hegemony become such an important thing in Gramscian hegemony theory. The intellectuals in the country had a role in Gramsci's theory of hegemony. Gramsci's concept of intellectual interpretation is that everyone has a function as an organizer in all levels of society in the areas of production as well as in the area of politics and culture. ${ }^{42} \mathrm{NU}$ in this case, is being an organization that was used by Gus Dur in applying such a counter of Gramsci hegemony. The Cultural zone involves forging process of thinking, mastery of the ideas of a general nature by linking cause and effect. ${ }^{43}$ Political region regarding political policy area that is dominating.

Islam nusantara profoundly diverse on models (configurations). Therefore, it is difficult to assert the existence of a homogeneous form of Islam Nusantara. Islam Nusantara is Islam diverse unique at the same time, said John 1. Esposito, an Islamisist of Georgetown University when he came at first time to Indonesia at the end of 2010. Because of the various configurations of Islam Nusantara, things could be tracked so why is there a diverse configuration of Islam? Some of Islamicscholars such as William Shepartz, said that the various configurations of

40Azyumardi Azra, Islam, Democracy and Civil Society, (Jakarta : ICIP, 2007), p. 35

${ }^{41}$ M. Amin Abdullah, Dinamika Islam Kultural, (Bandung: Mizan, 2006), p. 23

42Simon, Gagasan-gagasan, p. 141

43 A. Pozzolini, Pijar-pijar Pemikiran Gramsci. (Yogyakarta: Resist Book, 2005) 
Islam nusantara because the background that affected someone in Islam. Educational background, a reading that is accessed, the association, history even the Psychology ofsomeone will affect configuration of Islam which is embraced. It certainly will be more about the configuration of Islam Nusantara, but as a "picture" some configurations of Islam Nusantara can explain that Islam Nusantara had many experienced in such a significant change. There are many factors and effected on national politics in general. This type of Islam which is going to be a sect in Indonesia will all be determined by the conditions of the social, political, economic, cultural and psychological of Muslim in Indonesia.

According to Gramsci, the spreading is occurred not by itself, but through specific social institutions which became its center, for example, forms of schools and teaching, dominanted social groups, and so forth. The centers have the functionaries who have such an important role, namely the intellectuals. ${ }^{44} \mathrm{As}$ a methodology, the process of hegemony necessitates the emergence of counterhegemony, as well as an attitude of resistance of the classes possessed. ${ }^{45} \mathrm{NU}$ with good social resources of educational institutions, schools and social institutions to move manifests the indigenization of Islam until today lifted the discourse of Islam Nusantara.

The external factors may consider internal factors Islam Nusantara may provide a more adequate to see the configuration of Islam Nusantara in the future. Islam Nusantara is not the same as cultural Islamic movement, even the movement of cultural Islam can influence social and political conditions of national and even international. Strictly speaking, the form of local wisdom in the archipelago is a value system that has long been recognized by Islam. Like the pre-Islamic Arab land, ${ }^{46}$ some rules or traditions that exist, adopted by Islam. Usul al-figh, know syar'u man qablana and al-' urf approach. Khalil Abdul Karim, via its deep expressed the existence of adjustment of the Islamic culture of preIslamic Arabia. Nur Kholis mentioned that such a mix of Islam and local culture in the field of economy in Indonesia as one of the faces of Islam of Nusantara. ${ }^{47}$ With the elegant, m. Dawam Rahardjo also said its analysis :

"...Kesadaran akan hak milik mulai melemah ketika Islam masuk ke pedalaman pedesaan dan menyebar di kalangan masyarakat petani yang hidup dalam sistem feodal, di mana tanah dan sumber daya alam lainnya adalah milik raja. Kesadaran itu menjadi semakin melemah dengan masuknya sistem Tanam Paksa, di mana pemerintah kolonial menguasai sumberdaya alam melalui penguasaan sumber daya manusianya, yakni tenaga kerja petani. Dalam sistem ekonomi dan sistem politik ini Islam mengalami penyesuaian. Dengan penyesuaian itu, kemurnian Islam memang

44Faruk, Pengantar Sosiologi Sastra (Yogyakarta: Pustaka Pelajar, 2005), p. 77.

45S Hobden \& R.W. Jones, "Marxist Theories of International Relations", in S. Smith \& J. Baylis (eds). The Globalization of World Politics: An Introduction to International Relations (Oxford: Oxford University Press, 2001), p. 211.

${ }^{46}$ Khalil Abdul Karim, Syari'ah: Sejarah Perkelahian Pemaknaan, terj. (Yogyakarta: LKIS, 2003), p. 21

${ }^{47}$ Nur Kholis, Wajah Islam Nusantara, (Yogyakarta : Pustaka Ilmu, 2009), p. 19 
berkurang, tetapi Islam berkembang menjadi agama rakyat (folks-religion). Inilah yang menimbulkan apa yang oleh Gellner disebut sebagai "low Islam"atau Islam 'rendah' yang lebih emosional, mistik dan kolektif." 48

However, the dialectics of Islam Nusantara has experienced infidelity when met with colonialism. Islam nusantara experienced; What is called by Homi K. Bhabba as mimicry; a kind of cultural imitated or aggerated copying of anex language, culture, manners, and ideas, in the language of Bhabba. ${ }^{49}$ The capture of that culture, shaped double articulation something that is almost the same, but similar. On the other hand, mimicry also means booing (Mockery). Mimicry, said Ahmad Baso, always formed inter dicta, ie between cross between what is known and allowed (to know) and that can be known, tatapi forbidden and must be sealed. 50

The encountering between Islam Nusantara and the burned imprinted collective memory which made both tarnished. On the one hand, there is the Islamic dream with Arab style (Makkah-Madinah), but on the other hand, local wisdom seems to bind the heart to live with traditions of their ancestors. There was a great sense of imagination which presents refraction alienation local wisdom when dealing with the will of the times. Islam and local wisdom used as a political tool to confirmated of colonial powers which later inherited by the government after Indonesia's independence as if defending the law but its main intention is encircled space for Islamic values and local wisdom. ${ }^{51}$ Islam sensed consciously in public life for Christian Snouck is a threat to Dutch. ${ }^{52}$

Although the theory receptie Hurgronje gets fierce opposition from Sayuthi Thalibdan Hazairin through theoryexit and the theory reception a contrario, when viewed with an approach to post-colonial, it thus exposes the colonial hegemony of reason over the successfull of the Islamic Nusantara. Due to feeling threatened (feeling threatened) is not the implementation of legislation and the enactment of the indigenous. In fact, the custom which is the wisdom of the archipelago that has long been synergize with Islamic values. ${ }^{33} \mathrm{Gramsci}$ developed the concept of hegemony with the leadership rests on the intellectual and moral ' nature '. Leadership is occurring due to the voluntary consent of the

48M Dawam Rahardjo, Islam dan Transformasi Sosial-Ekonomi, (Jakarta: LSAF, 1999), h. 55 ${ }^{49}$ David Huddart, Homi K. Bhabha, (London\& New York, Routledge, 2006), p. 39

${ }^{50}$ Ahmad Baso, Islam Pasca Kolonial: Perselingkuhan Agama, Kolonialisme, dan Liberalisme, (Bandung: Mizan, 2005), p. 68

${ }^{51}$ Abdurrahman Wahid, Mengurai Hubungan Islam dan Negara(Jakarta: Grasindo, 1999), p. 74.

52Aqib Suminto, Politik Islam Hindia Belanda, (Jakarta: LP3ES, 1985), h. 11-12

${ }^{53}$ Not surprisingly, the relationship between Islam throughout the history of Islam archipelago is a political connection, and eventually spawned the ideological poles of Islam different from each other, such as the Islamic traditionalist, modernist Islam, and Islamic fundamentalism. It is then not only has implications for how Muslims view Islam as a religion, but Islam as a political reason. See also, Rizal Sukma, Islam in Indonesia. Policy, (NewYork: Routledge, 2003), p. 22 
lower class or society against the upper classes who leads, ${ }^{54}$ especially the approval of the main groups in a society.

As we observe in everyday life, Islam became the normative framework of the nation of Indonesia because the majority of adherents. Therefore, in all fields, including the field of law is often influenced by the thinking and understanding in society. Moreover, the coming of Islam to Indonesia are peaceful and way up which allow the occurrence of cross-culture process between Islam and the local culture which in turn formed the plural religious understanding. The concept of the intellectual interpretation of Gramsci is everyone that functions as an organizer in all walks of life in the region of production as in the area of politics and culture. ${ }^{55}$ Cultural area it concerns the process of forging the thinking, mastery of ideas that are common with the associate cause and its consequence. ${ }^{56}$

Islam Nusantara in Orthodoxy Islam Nusantara simply has three main elements, the first, kalam (theology) Asy'ariyah; second, Shafi'i fiqh - though also received three other Sunni schools of fiqh; third, Sufism al-Ghazali, both practiced individually or communally or through a more organized Sufi orders complete with mursyid, caliphs and pupils, and the ordinances of specific remembrance. As a comparison, the Islamic orthodoxy archipelago is different from the orthodoxy of Islam Saudi Arabi. In two conferences with members of the Ulama and intellectuals of Saudi Arabia in Riyadh and wadi about 300 kilometers from Riyadh (3-7 / 1), the author of 'Resonance' is declared, the Islamic orthodoxy Saudi Arabia contains only two elements, the first, kalam (theology) Salafi-Wahabi Islam with a literal understanding of Islam and the emphasis on 'pure'. ${ }^{57}$ This counter hegemony will continue running, if it received the support of the role of the organic intellectual and civil society where the powerless. In the end what has been discoursed Gus Dur slowly but surely saved archipelago culture on foreign cultural hegemony. Indigenization of Islam and Islam Nusantara become the hallmark of Indonesian Islam that respects plurality, tolerance and rahmatan lil Alamin.

\section{Conclusion}

As disclosed Azyumardi Azra that the worsening position of Muslim states in the north-south conflict into a major support emergence of radicalism. The formalization of Islamic Sharia is the primary concern for a long time Gus Dur. At the end of this movement negates the dialogue between cultures as mixing up the order of Arabic culture with Islamic values. Gramsci calls this condition as a hegemony. That ' hegemony ' happened with the source mastery ideology. Arab

54 Gramsci, Antonio. Selection From The Note Hoare and Nowell Smith (ed). New York: International Publishers. 1976. 142

55 Roger Simon, Gagasan-Gagasan Politik Gramsci, (Yogyakarta: Pustaka Pelajar, 1999),p. 141 -

56A. Pozzolini, Pijar-pijar Pemikiran Gramsci. (Yogyakarta: Resist Book, 2005)

${ }^{57}$ Azyumardi Azra, Islam Nusantara1, Republika, 18 Juni 2015 
hegemony for example will take place in the archipelago with the result in the value of existing local clash. Hegemony is done persuasively in the form instill ideology to dominate the mind of society in classes or layers underneath, without any coercion. Hegemony is achieved politically through efforts to create a moral and intellectual uniformity of views in a society. Hegemony in another sense also done by those who affected the foreign culture there by eliminating local values are good.

Gramsci developed the concept of hegemony with its leadership rests on 'the intellectual and moral'. Leadership is due to the voluntary consent of the lower class or upper class of society to lead, particularly approval of the major groups in a society. The model for the Islamic-inclusive and pluralist character of Islam substansialisme often collide with the formalization of Islamic law in Indonesia models Indonesian Mujahideen Council (MMI), Hisbut Tahrir Indonesia (HTI), the Islamic Defenders Front (FPI), and the Muslim Forum (FUI). Gus Dur, along with his conception of Pribumisasi Islam, has instilled moral and intellectual movement to preserve local traditions are fused with religious values. Until the narrative of Islam Nusantara echoed NU as part of efforts to deter robed religious radicalism. Islam Nusantara became narrative as well as the movement of counter hegemony over religious radicalism which ultimately generated a lot of civilian casualties in many countries. The phenomenon is part of radicalism in the name of religion were very militant build from the grassroots movement.

\section{Reference}

--------, "Yang Samadan Yang Benar" diterbitkan kembali dalam kumpulan tulisannya, Tuhan Tidak Perlu Dibela (Yogyakarta: LKiS, 1999)

----, Islam, Democracy and Civil Society, (Jakarta : ICIP, 2007)

--------, Islamku, Islam Anda dan Islam Kita, (Jakarta : The Wahid Institute,2008)

--------, Mengurai Hubungan Islam dan Negara (Jakarta: Grasindo, 1999), 74.

------, NU Studies: Pergolakan Pemikiran aatara Fundamentalisme Islam dan Fundamentalisme Neo-Liberal (Jakarta: Erlangga, 2006)

-------, Pergulatan Negara, Agama, dan Kebudayaan (Jakarta: Desantara, 2001)

-------, Tabayun Gusdur: Pribunisasi Islam, Hak Minoritas, Reformasi Kultural (Yogyakarta: LKiS,1998), 235.

------,Islamic Political Upheaval, from the Fundamentalist, Modernism to PostModernism, (Jakarta: Paramadina, 1996)

------,Shari'at Islam dalam Bingkai Nation State (Jakarta: Paramadina, 2004)

Abd Moqsith Ghazali dan Mustafa Basyir Rasyad, Islam Pribumi: Mencari Model Keberislaman ala Indonesia", dalam Komaruddin Hidayat dan Ahmad Gaus Af (ed.) Menjadi Indonesia: 13 abad Eksistensi Islam di Nusantara, Mizan, (Bandung: Mizan, 2006)

Abdurrahman Wahid, "Pribumi Islam" dalam Muntaha Azhari\& Abdul Mun'im Saleh (eds.), Islam Indonesia Menatap Masa Depan (Jakarta: P3M, 1989)

Abdurrahman, Moeslim.Islam sebagai Kritik Sosial, (Jakarta: Penerbit Erlangga, 2003) 
Agastya.M.ABM,Arab Spring Badai Revolusi Timur Tengah yang Penuh Darah. (Jogjakarta: IRCiSoD, 2013)

Ahmad Baso, Islam Pasca Kolonial: Perselingkuhan Agama, Kolonialisme, dan Liberalisme, (Bandung: Mizan, 2005)

Ahmad Syafii Maarif, Islam dan Masalah Tata Negara, (Jakarta : LP3ES, 1987)

Aqib Suminto, Politik Islam Hindia Belanda, (Jakarta: LP3ES, 1985)

Azyumardi Azra, Agama dan Otentisitas Islam (Jakarta: Paramadina, 2004)

Bahtiar Effendy dan Hendro Prasetyo. Radikalisme Agama.(Jakarta :PPIM, 1998)

Bocock, Robert,Pengantar Komprehensif untuk Memahami Hegemoni, terj. Ikramullah Mahyuddin (Yogyakarta: Jalasutra, 2007), hlm. 22-23

David Huddart, Homi K. Bhabha, (London \& New York, Routledge, 2006)

Dedi Junaidi, Beyond the Symbols: Jejak Antropologis Pemikiran dan Gerakan Gus Dur (Bandung: PT. Remaja Rosda Karya, 2000)

Faruk, Pengantar Sosiologi Sastra (Yogyakarta: Pustaka Pelajar, 2005)

Gramsci, Antonio. Selection From The Note Hoare and Nowell Smith (ed). New York: International Publishers. 1976.

Greg Barton, Biografi Gus Dur (Yogyakarta: LKiS, 2006)

Haidar Assad, Muhammad. ISIS Organisasi Teroris Paling Mengerikan Abad Ini. (Jakarta: Zahira, 2014)

\section{Journal/Paper}

Khalil Abdul Karim, Syari'ah: Sejarah Perkelahian Pemaknaan, terj. (Yogyakarta: LKIS, 2003)

Khamami Zada dkk.,"Islam Pribumi: Mencari Wajah Islam Indonesia", dalam Jurnal Tashwirul Afkar, No. 14 (Jakarta: Lakpesdam, 2003)

Kholiq,Nur.Pribumisasi Islam Dalam Perspektif Gus Dur: Studi Kritis Terhadap Buku Islamku, Islam Anda, Islam Kita". (Skripsi UIN Sunan Kalijaga Yogyakarta: 2010)

Kholis, Nur.Wajah Islam Nusantara, (Yogyakarta : Pustaka Ilmu, 2009)

M Dawam Rahardjo, Islam dan Transformasi Sosial-Ekonomi, (Jakarta: LSAF, 1999)

M. Amin Abdullah, Dinamika Islam Kultural, (Bandung: Mizan, 2006)

M. Clark, Antonio Gramsci and the Revolution that Failed (New Haven: Yale University Press,1977)

M. Imaduddin Rahmat, Arus Baru Islam Radikal, Transmisi Revivalisme Islam Timur Tengah ke Indonesia (Jakarta: Erlangga, 2005)

M. Khoirul Hadi, Abdurrahman Wahid dan Pribumisasi Pendidikan Islam, Hunafa: Jurnal Studia Islamika, Sekolah Tinggi Islam Syalafiyyah Kencong Jember. Jurnalhunafa.org, Vol. 12, No. 1, Juni 2015: 183-207

Madjid, Nurcholis.Islam, Doktrin dan Peradaban (Jakarta: Paramadina, 1992)

Martin van Bruinessen, "Global and local in Indonesian Islam" Shouteast Asian Studies Vol.37 No.2 (1999), h. 158-175; dan Azyumardi Azra, Islam Nusantara: Jaringan Global dan Local (Bandung: Mizan, 2002)

Ninin Prima Damayanti, Imam Thayibi, Listya Adi Gardhiani, Indah Limy, Radikalisme Agama Sebagai Salah Satu Bentuk Perilaku Menyimpang: Studi Kasus Front Pembela Islam, Jurnal Kriminologi Indonesia Vol. 3 No. I Juni $2003: 43-57$

Qodir, Zuly.Pembaruan Pemikiran Islam, (Yogyakarta : Pustaka Pelajar, 2006)

R.E. Elson, "Islam, Islamism, the Nation and the Early Indonesian Nationalist Movement" Journal of Indonesian Islam Vol.1 No.2 (2007), 231-266. 
Simon, Roger. Gagasan-Gagasan Politik Gramsci, (Yogyakarta: Pustaka Pelajar, 1999), hlm. $141-142$

Sukma, Rizal Islam in Indonesia Foreign Policy, (NewYork: Routledge, 2003)

WS Rendra,Mempertimbangkan Tradisi. (Jakarta: PT Gramedia, 1981)

Zada, Khamami.Islam Radikal : Pergulatan Ormas-ormas Islam Garis Keras di Indonesia, (Jakarta : Teraju, 2002)

Zainul Milal Bizawie, "Dialektika Tradisi Kultural: Pijakan Historis dan Antropologis Pribumisasi Islam", dalam Jurnal Tashwirul Afkar, No. 14 (Jakarta: Lakpesdam, 2003)

Zeyno, Baran.Hizbut-Tahrir, Islam's Political Insurgency (Washington: The Nixon Center, 2004)

\section{Internet/News Paper}

Azyumardi Azra, Islam Nusantara, Koran Republika, 18 Juni 2015

Djohan Effendy, Pembaruan tanpa Menabrak Tradisi, (Kompas, 2010)

http://www.jpnn.com/read/2015/06/14/309550/Jokowi:-Alhamdulillah,Islam-Kita-Islam-Nusantara diunduh 20 Juli 2016

http://www.nu.or.id/post/read/59035/apa-yang-dimaksud-dengan-islamnusantara diunduh 20 Juli 2016 